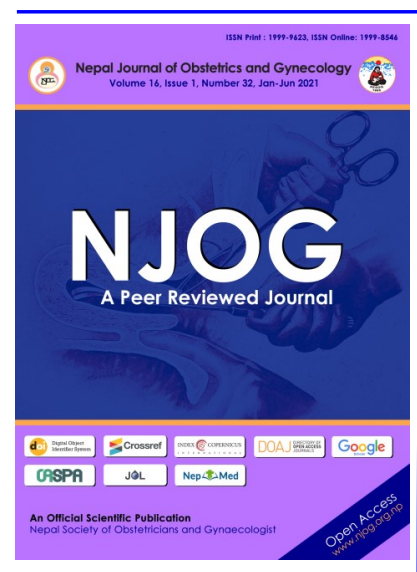

CORRESPONDENCE

Dr Poonam Lama

Department of Obstetrics and Gynecology,

Paropakar Maternity and Women's Hospital,

Kathmandu, Nepal

Email: drpoonamlama@ gmail.com;

Phone: +977-9808033906

Received: January 24, 2021

Accepted: May 15, 2021

\section{Citation:}

Lama P, Pariyar J. Histological analysis of the products of conception in first trimester spontaneous abortions. Nep J Obstet Gynecol. 2021;16(32):31-33.

DOI: https://

doi.org/10.3126/

njog.v16i1.37512

\title{
Histological analysis of the products of conception in first trimester spontaneous abortions
}

\author{
Lama Poonam $^{1}$, Jitendra Pariyar ${ }^{2}$ \\ ${ }^{1}$ Department of OBGYN, Paropakar Maternity and Women's Hospital, \\ Kathmandu, Nepal \\ ${ }^{2}$ Department of OBGYN, Civil Service Hospital, Kathmandu, Nepal
}

\section{ABSTRACT}

Aims: To evaluate the histopathological findings of products of conception in the first trimester spontaneous abortions.

Methods: A hospital based descriptive cross sectional study conducted from March 2018 to March 2019, among the women admitted with diagnosis of first trimester spontaneous abortion at Paropakar Maternity and Women's Hospital.

Results: Among 80 cases of spontaneous abortions, incomplete abortion was the commonest type constituting $42.5 \%$ of the studied group. The majority of participants belonged to age group of $21-30$ years $(61.2 \%)$ with a mean age of $26.8 \pm 6.1$ years. Histopathologic examination confirmed products of conception in $60(75 \%)$ patients, partial molar pregnancy in $9(11.25 \%)$ patients, decidual reaction in $9(11.25 \%)$ patients and hydropic abortus in only $2(2.5 \%)$ patients. The molar pregnancy was more prevalent among women of Tibeto-Nepalese ethnic group $26.5 \%(\mathrm{n}=9)$. Partial hydatidiform mole was more common in primiparous (19.3\%) than in multiparous (14.2\%).

Conclusions: The histopathological examination of the products of conception proved to be an important tool in detecting undiagnosed pathology like molar pregnancy and hydropic changes that necessitate special follow-up protocol and further management.

Keywords: abortion, histopathology, hydropic changes, molar pregnancy

\section{INTRODUCTION}

The World Health Organization defines abortion as pregnancy termination before 20 week gestation or a fetus born weighing less than 500 grams. ${ }^{1}$ It is the most common complication of pregnancy and more than $80 \%$ of spontaneous abortion occurs in the first 12 weeks. ${ }^{2-4}$

Histopathological examination (HPE) of products of conception (POC) is an integral and routine component of the management of patients with early pregnancy failure. ${ }^{5}$ The basic surgical principle that any tissue obtained from the body is better subjected for HPE is utmost important in cases of spontaneous abortion. The main rationale is, firstly, to confirm that intrauterine pregnancy has existed and secondly, to exclude gestational trophoblastic disease (GTD) which is potentially premalignant and necessitates special follow up. Other reasons include determining the cause of recurrent pregnancy loss or detecting unexpected fetal pathology.
In most centers it is a routine practice to send the tissue obtained from uterine evacuation after abortions for HPE not only for above reasons but also for medico legal purposes. ${ }^{7}$ In addition from the medicolegal aspect, it is beneficial in protecting obstetrician and gynecologist from medicolegal recrimination, but is unclear whether this practice is medically justified. ${ }^{8}$ However till date both school of thoughts pertain, stating the necessity and no necessity of HPE following abortion.

\section{METHODS}

This was a hospital based descriptive cross sectional study conducted at Paropakar Maternity and Women's Hospital, Kathmandu, Nepal from March 2018 to March 2019. Those cases with medical termination of pregnancy and ectopic pregnancy including those who failed to provide consent were excluded from this study. 
Obtained POC were stored in a container with formalin 10\% immediately after the evacuation and sent to the histopathology laboratory. The samples underwent gross examination before being embedded in paraffin blocks for further processing. The paraffin blocks were cut by a microtome into $4 \mathrm{~mm}$ sections and fixed onto slides, which were subsequently stained with hematoxylin and eosin method. The sections were examined microscopically by a pathologist and reported on. Additional follow up were adhered to hospital protocol or as planned by the attending team.

Data presented as mean \pm SD (standard deviation) and results were analyzed using SPSS 21 taking pvalue $=0.05$ was considered as significant .

\section{RESULTS}

Total 80 cases of spontaneous abortions were included in this study. The age of patients ranged from 19 to $40(26.8 \pm 6.1)$. The age group 21-30 years was the most frequently affected $(61.2 \%)$ followed by age group $\leq 20$ years $(17.5 \%)$. [Table-1]

Table-1: Age group wise distribution $(\mathrm{N}=80)$

\begin{tabular}{ccc}
\hline Age in years & $\mathrm{N}$ & $\%$ \\
\hline$\leq 20$ & 14 & 17.5 \\
$21-30$ & 49 & 61.2 \\
$31-40$ & 14 & 17.5 \\
$>40$ & 3 & 3.8 \\
\hline
\end{tabular}

The majority of participants belonged to IndoNepalese ethnic group $(n=41 ; 51.25 \%)$ followed by Tibeto-Nepalese $(\mathrm{n}=34 ; 42.5 \%)$ and Indigenous group $(\mathrm{N}=5 ; 6.25 \%)$. Most of the study participants were primigravida $(43.8 \%)$ followed by second gravida $(26.3 \%)$. [Table-2]

Table-2: Case distribution by parity

\begin{tabular}{ccc}
\hline Parity & $\mathrm{N}$ & $\%$ \\
\hline 1 & 35 & 43.8 \\
2 & 21 & 26.3 \\
3 & 15 & 18.8 \\
$\geq 4$ & 9 & 11.1 \\
\hline
\end{tabular}

The most common clinical diagnosis on admission was incomplete abortion in $42.5 \%$ cases. However, septic abortion was seen in only $2.5 \%$ cases. [Table3]

Table-3: Type of abortion on admission $(\mathrm{N}=80)$

\begin{tabular}{lcc}
\hline Type of abortion & $\mathrm{N}$ & $\%$ \\
\hline Incomplete & 34 & 42.5 \\
Missed & 33 & 41.3 \\
Blighted ovum & 11 & 13.7 \\
Septic & 2 & 2.5 \\
\hline
\end{tabular}

The HPE revealed the usual POC in 60 patients (75\%) followed by partial mole and decidual reaction. Two patients had suspicion of presence of other pathology, which required further evaluation. [Table-4]

Table-4: Histopathology report diagnosis $(\mathrm{N}=80)$

\begin{tabular}{lcc}
\hline HPE report & N & $\%$ \\
\hline POC & 60 & 75 \\
Partial mole & 9 & 11.25 \\
Decidual reaction & 9 & 11.25 \\
Others & 2 & 2.50 \\
\hline
\end{tabular}

\section{DISCUSSION}

Abortion is a common condition in the first trimester of pregnancy and like many other disorders, an accurate diagnosis is necessary for the management. There is controversy regarding the practice of routine HPE of tissue removed during abortion. Some authorities suggest that tissue from all uterine evacuations should be submitted for histopathological assessment: first to confirm pregnancy, second to exclude an ectopic pregnancy or GTD and third to search for the causes of abortion. $5,8,9,10,11$

In the present study, majority of women belonged to age group of $21-30$ years $(61.2 \%)$ with mean age of 26.8 years. Similar findings were noted in study done by Makaju R et al in $2015 .{ }^{12}$ Independent of the effect of age, the risk of early pregnancy loss increases with increasing parity. However, in our study, most of the study participants were primigravida (43.8\%) followed by second gravida $(26.3 \%)$. A study done by Matovelo et $\mathrm{al}^{13}$ and colleagues showed similar results where majority of the patients were primigravida $(56.1 \%)$.

In the present study, the majority of patients $(42.5 \%)$ were admitted with diagnosis of incomplete abortion. This is in agreement to a study conducted by Rashid et al which revealed incomplete abortion in $65.3 \%$ cases. ${ }^{14}$ POC was the most common histolopathologic findings which accounted to be $75 \%(n=60)$ in the present study. Thapa et al reported similar findings in $238(86.54 \%)$ cases amongst 275 specimens. ${ }^{15}$ The present study reported hydropic abortus in only $2(2.5 \%)$ cases. Contrarily to our study, a study conducted by Shetty et al reported higher number of hydropic abortus in their specimens $(32 \%){ }^{16}$

In this study, PHM was reported in $9(11.25 \%)$ patients in histopathological analysis. Similar to our study, many studies have revealed the higher percentage of molar pregnancy in histopathologic analysis of spontaneous abortions. In a study by Pariyar J et al, a total of 45 cases of GTD were analyzed which revealed $35.5 \%$ cases of GTD had occurred following abortion. ${ }^{17}$ This study revealed that the highest percentage of patients, $26.5 \%$ who 
belonged to tibeto-nepalese ethnic group were found to have PHM and this data was found to be statistically significant ( $\mathrm{p}$ value $<0.05$ ). These results are consistent with the study done by Pariyar $\mathrm{J}$ et $\mathrm{al}^{17}$ which revealed more cases of GTD, 19 cases (43\%) among Tibeto-Burmese ethnic group with higher incidence of malignant sequelae as well.

Since PHM may have symptoms of incomplete or missed abortion and the definitive diagnosis is usually made after HPE of the specimen. For this reason, the submission of the tissue specimens obtained during evacuation for all abortions is very important because unsuspected molar pregnancy may result in profound clinical consequences. The incidence of GTD in the region is a factor that may affect the value of routine HPE of obtained tissues. In Asia the incidence of $\mathrm{HM}$ is as high as 1 in 80 pregnancies, unlike the western countries where it is 1 in 5001500 pregnancies, thus, highlighting the importance of a routine HPE of the abortus.

Nevertheless, the limited sample size and a single center study can effect in the interpretation of the obtained result. Therefore, sample size can be increased to incur more concrete result.

\section{CONCLUSIONS}

Besides confirming pregnancy in early trimester abortion by histopathological examination, this would be an important tool in detecting molar pregnancy and hydropic changes that necessitate special follow-up protocol.

\section{REFERENCES}

1. Cunningham FG, Leveno KJ, Bloom SL, Spong CY, Dashe JS, Hoffman BL, et al. Abortion. Williams Obstetrics. $24^{\text {th }}$ ed. USA: McGraw Hill Education; 2014. p. 312-4.

2. Hill LM, Guzick D, Fries J. Fetal loss rate after ultrasonically documented cardiac activity between 6 and 14 weeks, menstrual age. J Clin Ultrasound. 1991;19;221-3.

3. Juliano M, Dabulis S, Heffner A. Characteristics of women with fetal loss in symptomatic first trimester pregnancies with documented fetal cardiac activity. Ann Emerg Med. 2008;52:143-7.

4. Wyatt PR, Owolabi T, Meier C. Age-specific risk of fetal loss observed in a second trimester serum screening population. Am J obstet Gynecol. 2005;192:240-6.

5. Hinshaw K, Fayyad A. The management of early pregnancy loss. RCOG Guidelines. 2000. URL: http://www.rcog.org.uk/index.asp?PageID=515

6. Cunningham FG, Leveno KJ, Bloom SL, Spong CY, Dashe JS, Hoffman BL, et al. Abortion. Williams Gynecology. $3^{\text {rd }}$ ed. USA: McGraw Hill Education; 2016. p. 137-8.
7. Alsibiani SA. Value of Histopathologic Examination of Uterine Products after First-Trimester Miscarriage. BioMed Res Int. 2014;1:1-5.

8. Fulcheri E, Di CE, Ragni N. Histologic examination of products of conception at the time of pregnancy termination. Int J Gyn Obst. 2003;80 (3):315-6.

9. Fram KM. Histological analysis of the products of conception following first trimester abortion at Jordan University Hospital. Eur J Obstet Gynecol Reprod Biol. 2012;105:147-9.

10.Tasci Y, Dilbaz S, Secilmis O, Dilbaz B, Ozfuttu A, Haberal A, et al. Routine histopathologic analysis of product of conception following first-trimester spontaneous miscarriages. J Obstet Gynecol Res. 2005;31(6):579-82.

11.El-Halaby O, AbdElaziz O, Elkelani O, Abo Elnaser M, Sanad Z, Samaka R. The value of routine histopathological examination of products of conception in case of first trimester spontaneous miscarriage. Tanta Med Sc J. 2006;1(4):83-8.

12. Makaju R, Shrestha S, Sharma S, Dhakal R, Bhandari S, Shrestha A, et al. Histopathological Changes in the Chorionic Villi and Endometrial Decidual Tissues in the Product of Conception of Spontaneous Abortion Cases. Kathmandu Univ Med J. 2015;52(4):357-60.

13. Kitange B, Matovelo D, Konje E, Massinde A, Rambau P. Hydatidiform moles among patients with incomplete abortion in Mwanza City, north western Tanzania. African Health Sc. 2915; 15:1081-86.

14. Rashid PA. The role of histopathological examination of the products of conception following first-trimester miscarriage in Erbil Maternity Hospital. Zanco. J Med Sc. 2017;21(3).

15. Thapa R, Mishra P. The striddling transfiguration and clinicopathological examination of products of conception after first trimester miscarriages- two year study in a tertiary care centre in north eastern part of the country. Int $\mathrm{J} \mathrm{Sc}$ Res. 2018;7(6).

16. Shetty A, Narasimha A. Histopathological Study of Villous Morphology in Spontaneous First Trimester Abortions. Annal Path Lab Med. 2016;03(05):451-7.

17.Pariyar J, Shrestha B, Shrestha J, Rauniyar BP, Regmi SC. Gestational trophoblastic disease: review of cases managed at B P Koirala Memorial Cancer Hospital. NJOG. 2013;8(1):18-21. 